\title{
EFFICIENCY EVALUATION OF AN ALGISTATIC TREATMENT BASED ON BARLEY STRAW IN A HYPERTROPHIC POND
}

\author{
Emilie Prygiel $^{\mathrm{a}}$, Adeline Charriau ${ }^{\mathrm{a}, \mathrm{b}}$, Romain Descamps ${ }^{\mathrm{a}}$, Jean Prygiel $^{\mathrm{a}, \mathrm{c}}$, \\ Baghdad Ouddane $^{\mathrm{a}}$, Gabriel Billon ${ }^{\mathrm{a}}$ \\ ${ }^{a}$ Géosystèmes, UMR 8217 CNRS - University Lille 1, Villeneuve d'Ascq, France \\ ${ }^{b}$ Research Group on Water, Soil and the Environment EA 4330, Faculty of Sciences and Technology, \\ University of Limoges, France \\ ${ }^{c}$ Artois-Picardie Water Agency, Douai, France \\ Submitted 16 Oct. 2012; accepted 30 Apr. 2013
}

\begin{abstract}
Eutrophication processes were closely examined in a hypertrophic pond that was subjected to a barley straw treatment to inhibit cyanobacteria blooms. A phytoplankton activity was present from February to November 2010 with Chlorophyll $a$ concentrations that ranged between 8 and $83 \mu \mathrm{g} \mathrm{L}{ }^{-1}$. The good oxygenation of the pond provided by primary production all along the year seems to maintain an oxic layer at the top of the sedimentary column. A high-frequency monitoring of algal development pointed out the end of the diatom bloom at the end of April and the growth of green algae from beginning of May. One month later, the development of cyanobacteria supplanted other algae several times. The implementation of barley straw does not seem to hinder the growth of cyanobacteria in June, August and September and do not promote the development of other algae potentially favoured by such a treatment. As a consequence, a barley straw treatment does not seem to be really appropriate for this kind of ponds in Northern France and more tests should still be undertaken to prove its real efficiency.

Keywords: eutrophic pond, sediment, nutrients, phytoplankton, environment monitoring, barley straw.

Reference to this paper should be made as follows: Prygiel, E.; Charriau, A.; Descamps, R.; Prygiel, J.; Ouddane, B.; Billon, G. 2014. Efficiency evaluation of an algistatic treatment based on barley straw in a hypertrophic pond, Journal of Environmental Engineering and Landscape Management 22(1): 1-13. http://dx.doi.org/10.3846/16486897.2013.801847
\end{abstract}

\section{Introduction}

Input of an excess of nutrients, especially phosphorus, in relative closed systems, where water flow is low and water residence time is high, can result in algal proliferations, and particularly cyanobacteria blooms (Bai et al. 2009; Kisand 2005). In Europe, the most common cyanobacteria gena are Microcystis, Anabaena, Aphanizomenon, Oscillatoria, Nodularia and Nostoc. Although primary production necessitates at least carbon dioxide, nitrate, phosphate and silicate, it has been generally observed in freshwater ponds where nitrate and/or phosphate are the main limiting factors of algal development. More precisely, in hypertrophic lakes/ponds, where phosphate can reach high concentrations, phosphorus cannot be efficiently removed from water bodies with gaseous species $\left(\mathrm{H}_{3} \mathrm{P}\right)$ and is progressively accumulated in sediments, and to a lesser extent in water (Cao et al. 2011; Xiang, Zhou 2011). Nitrate can, therefore, be the limiting nutrient permitting the proliferation of heterocystous cyanobacteria (O’Neil et al. 2012, and references therein), even if other interacting hydrodynamic and climatic parameters also play a key role in such excessive algal development (mixing conditions, sunlight, food web structure, water temperature, transparency and residence time) (Khan, Ansari 2005). In freshwater environments, when nitrogen becomes the limiting factor (that is generally characterised by the molar ratio N/P lower than 16) and nitrate concentrations drop down to $50-100 \mu \mathrm{g} \mathrm{L}^{-1}$, another source of nitrogen, like atmospheric $\mathrm{N}_{2}$, becomes necessary for algal development, especially in summer when light and temperature are optimal. In this case, only heterocystous cyanobacteria such as Anabaena, Aphanizomenon, Cylindrospermopsis, Nodularia and Nostoc are able to assimilate $\mathrm{N}_{2}$ (Paerl et al. 2006).

Several preventive actions and curative treatments, including the reduction of nutrient loadings from the catchment, the spreading of copper sulphate and limestone, and sediment dredging, may be applied to limit cyanobacteria blooms (Le Jeune et al. 2006). In the 1990s, a promising technique based on barley straw

Corresponding author: Gabriel Billon

E-mail: gabriel.billon@univ-lille1.fr 
decomposition was developed and applied successfully in several water bodies (Brownlee et al. 2003; Ó hUallacháin, Fenton 2010; Purcell et al. 2013). Both the way of action and the long-term efficiency of such a treatment are controversial (Hagström et al. 2010): the decomposition of the lignin present in straw produces polyphenolic compounds that have an algistatic effect on several cyanobacteria and other algae as well (Ferrier et al. 2005; Pęczuła 2013), whereas several phytoplankton species seem to be stimulated (Ferrier et al. 2005; Grover et al. 2007). Another hypothesis proposed by Everall and Lees (1997) and Iredale et al. (2012) is the production of hydrogen peroxide during the photooxidation of a particular type of lignin present in barley straw, and which is highly toxic towards phytoplankton.

The present work aims at studying the response of a hypertrophic lake (Pont-Rouge Pond, located in Northern France in the Artois-Picardie watershed) subjected to an algistatic treatment using barley straw. In this area, numerous ponds and lakes have experienced an increase in the frequencies of these blooms, in particular with the development of Microcystis and Planktothrix (Willame, Hoffmann 2005). As a consequence, harmful algal blooms threaten economic activities and appear as a crucial issue in terms of water quality degradation and human health (Newcombe et al. 2012). A chemical and biological monitoring was performed in 2010, before and during the treatment, to highlight its potential impact on algal development, and particularly on cyanobacteria proliferations. The fate of phosphorus, and to a lesser extent nitrogen, was in parallel closely examined in the water column and surface sediments; chemical redox indicators were additionally taken into account to predict the possible mobilisation of phosphate at the water-sediment interface during anoxic periods. Finally, this biogeochemical approach permits us to better understand the phytoplankton cycle in a hypertrophic pond and to point out the difficulties to fight against eutrophication processes.

\section{Materials and methods}

\subsection{Location and presentation of the site}

The Pont-Rouge Pond is a 13 ha water area located in the city of Le Quesnoy (Northern France, see Fig. 1). This pond was used in the past as a defence structure, with still existing ramparts, and is nowadays dedicated to leisure activities, including fishing and swimming. The pond is not a fully closed system, considering that it receives water from a small stream (L'Ecaillon stream, in the south-eastern part of the pond) during the rains, and that a water lock (north-western part of the pond) allows maintaining a constant water level. The average depth of the pond is $1.92 \mathrm{~m}$ with a maximal depth of $3 \mathrm{~m}$. The volume of the pond has

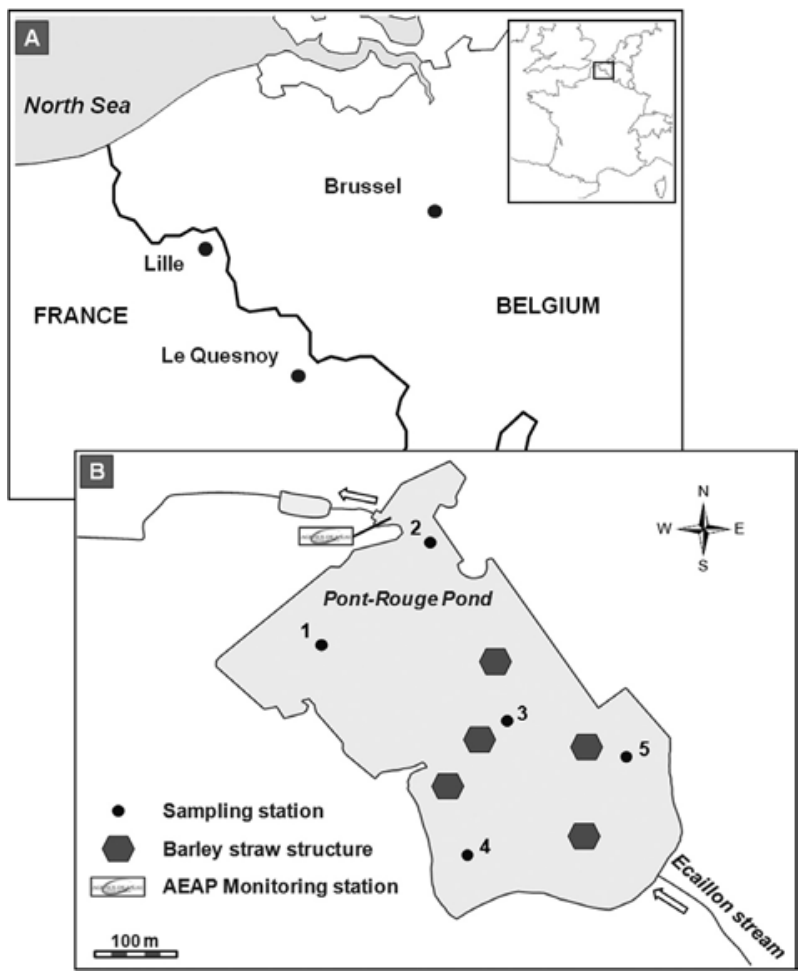

Fig. 1. Location of the city of Le Quesnoy (A) and map of the Pont-Rouge Pond including the location of sampling stations, barley straw structures and the monitoring station (B)

been estimated to be $240,000 \mathrm{~m}^{3}$ with an average flowing-through time approximately equal to 39 days. Cyanobacteria blooms were noticed for the first time in the 1990s. To fight against these proliferations, several preventive actions or treatments have been tested, such as chemical treatments with copper sulphate (1990), alumina sulphate (1991) and calcium salts (2006), reduction of phosphorus inputs (1994-1995), sediment dredging (2000) and implementation of oxygenation structures. However, an increase in the frequency of these blooms was registered, often with the presence of Anabaena sp, Aphanizomenon sp, Aphanothece sp and Planktothrix agardhii.

\subsection{Biogeochemical sampling and analysis}

Five sampling stations were defined in the pond to monitor physico-chemical, chemical and biological parameters in the overlying water and sediments from February to November 2010 (Fig. 2).

Dissolved oxygen, conductivity, $\mathrm{pH}$ and turbidity were measured in situ by using a WTW multimeter (Oxi 340) connected to appropriate electrodes and a turbidimeter (Hach Lange, TSS portable). A Secchi disk was also used to evaluate water transparency.

For each station, water samples, collected in acid pre-cleaned bottles, were filtered on cellulose acetate membranes (Alltech, $0.45 \mu \mathrm{m}$ ) and immediately frozen until nutrient analyses. For the determination of metal concentrations, $100 \mu \mathrm{L}$ of ultrapure nitric acid (Merck) 


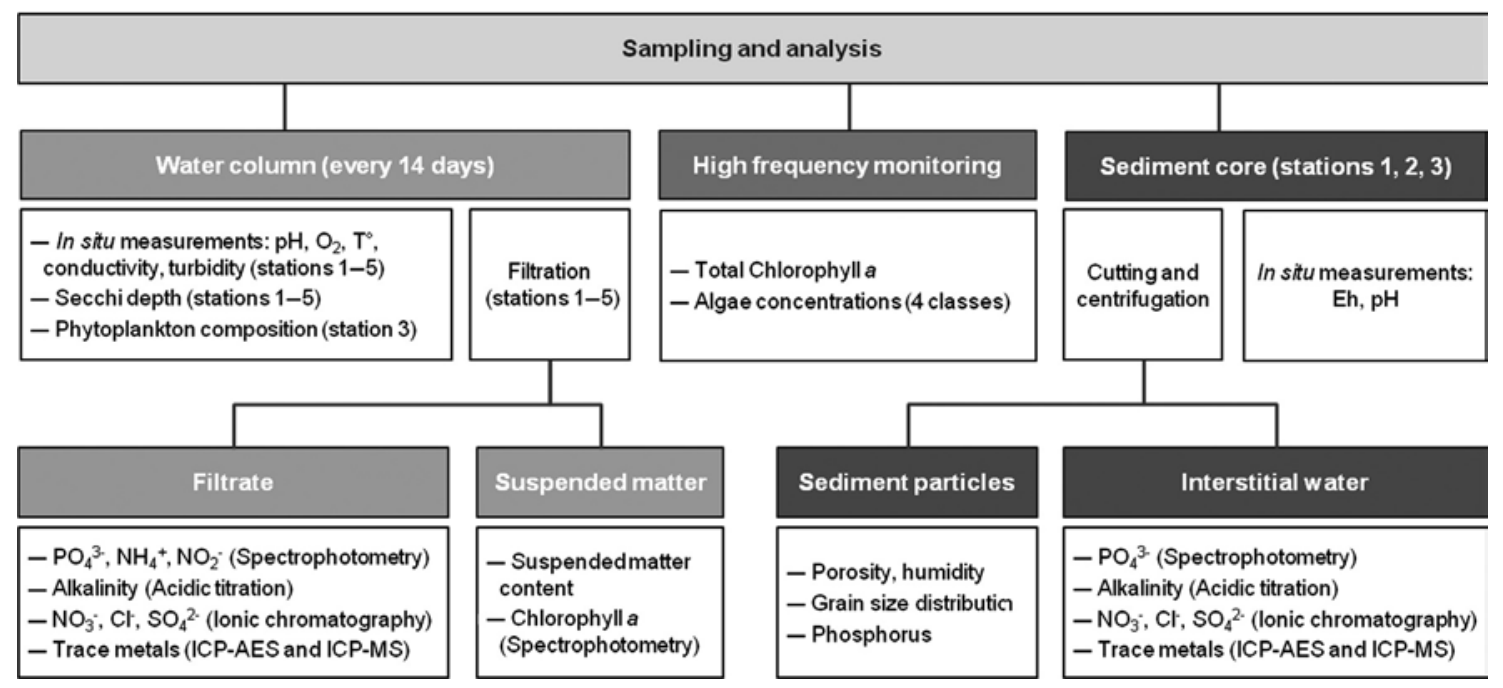

Fig. 2. Sampling and analysis design for water, sediment and phytoplankton

were immediately added to $10 \mathrm{~mL}$ of filtered samples that were kept at $4{ }^{\circ} \mathrm{C}$ until elemental analyses. Dissolved orthophosphate (also called DRP: Dissolved Reactive Phosphorus), ammonium and nitrite concentrations were determined according to standard spectrophotometric methods proposed by the International Organisation for Standardisation (ISO).

Measurements were performed using a spectrophotometer (Varian Cary 300 Scan UV-Visible) with a 5 -cm length sample cuvet. The limits of detection (LOD) were $10 \mu \mathrm{g} \mathrm{L}^{-1}$ for $\mathrm{PO}_{4}^{3-}$ and $2 \mu \mathrm{g} \mathrm{L}^{-1}$ for $\mathrm{NH}_{4}^{+}$and $\mathrm{NO}_{2}^{-}$. Nitrate contents were determined using an ionic chromatography (Dionex Ion Pac AS 18) with an LOD of $0.1 \mathrm{mg} \mathrm{L}^{-1}$. Alkalinity was estimated by titration (Metrohm 736 GP Titrino) with a $0.02 \mathrm{M}$ hydrochloric acid solution $\left(\mathrm{LOD}=0.2 \mathrm{mmol} \mathrm{L}^{-1}\right.$ ). Dissolved iron and manganese concentrations were measured in acidified water samples by ICP-AES (Inductively Coupled Plasma-Atomic Emission Spectroscopy) (Varian Vista Pro, axial view), with an LOD of 0.01 and $0.05 \mathrm{mg} \mathrm{L}^{-1}$, respectively. Suspended matters collected on glass fibre membranes (Whatman $\mathrm{GF} / \mathrm{F}, 0.7 \mu \mathrm{m}$ ) were immediately frozen until the determination of Chlorophyll $a(\mathrm{Chl}-a)$ concentrations. Briefly, filters were crushed into centrifugation tubes in the presence of $10 \mathrm{~mL}$ of a mixture acetone-Milli-Q water $(90-10, v / v)$, stored overnight at $4{ }^{\circ} \mathrm{C}$, and then centrifuged at $3000 \mathrm{rpm}$ for $15 \mathrm{~min}$. Chl- $a$ was measured in the supernatant using the previously mentioned spectrophotometer at the wavelength of $665 \mathrm{~nm}$.

Sediment samplings were carried out in stations 1, 2 and 3 in spring 2010 (04 March, 01 April and 20 April, respectively). At each station, 2 sediment cores were carefully collected using 35-cm-long Perspex tubes. The first one was used to assess directly in the field the profiles versus depth of $\mathrm{pH}$ and redox potential by using a glass electrode (Toledo Mettler, penetration type) and a platinum electrode (Toledo
Mettler), respectively, both combined with a $\mathrm{Ag} / \mathrm{AgCl}$, $[\mathrm{KCl}]=3 \mathrm{M}$, reference electrode. In the laboratory, the second core was dedicated to the analysis of iron, manganese, nitrate and phosphate concentrations in pore waters, as well as the water percentage, porosity, granulometric distribution and phosphorus contents in bulk sediment. For that purpose, the second core was sliced in 2-cm thick slices under a nitrogen atmosphere inside a glove box. A part of these sliced sediments was kept in plastic bags previously purged with $\mathrm{N}_{2}$ for solid analyses and the remaining part was centrifuged (2500 rpm for $20 \mathrm{~min}$ ) in order to recover supernatant waters. Centrifuge tubes were returned to the $\mathrm{N}_{2}$ flushed glove box, where pore waters were filtered with cellulose acetate membranes (Alltech, $0.45 \mu \mathrm{m}$ ) and immediately acidified with ultra-pure nitric acid $(100 \mu \mathrm{L}$ in $10 \mathrm{~mL}$ of pore water). Dissolved iron and manganese concentrations were measured as previously described. Total phosphorus concentrations in sedimentary particles were measured by spectrophotometry after the following extraction procedure. Briefly, dried sediments were first pyrolysed at $450{ }^{\circ} \mathrm{C}$ during 24 hours to mineralise phosphorus bound to organic matter. $200 \mathrm{mg}$ of sediment particles were then attacked with $3.5 \mathrm{M}$ hydrochloric acid during 24 hours at room temperature. The leaching solution was thereafter filtrated at $0.45 \mu \mathrm{m}$ and analysed by spectrophotometry after the formation of an antimony-phosphomolybdate complex, subsequently reduced in the presence of ascorbic acid. A standard sediment (CRM 684) was used to validate the protocol and the recovery was found to be better than $90 \%$. Granulometric distributions were evaluated with a laser granulometer (laser Malvern Mastersizer 2000).

\subsection{High-frequency phytoplankton monitoring}

An Algae Online Analyser (AOA, BBE Moldaenke) was deployed from May to June 2010 to record at a 
high frequency (1 measurement every $10 \mathrm{~min})$ the evolution of phytoplankton. The AOA was embedded in the Artois-Picardie Water Agency (AEAP) monitoring station located in the northern part of the pond just upstream from the water lock (Fig. 1). The pump allowing a continuous water sampling was immersed to a depth of $50 \mathrm{~cm}$. This autonomous fluorometer measures the concentrations of total Chl- $a$ and four classes of algae (Chlorophyceae, Bacillariophyceae, Cyanophyceae and Cryptophyceae) thanks to five light emitting diodes $(450,252,570,590$ and $610 \mathrm{~nm})$ exciting the characteristic pigments of phytoplankton groups. Additionally, in order to get a more accurate view of the phytoplankton composition, $1 \mathrm{~L}$ of water was sampled twice a month, at $30-\mathrm{cm}$ depth in the middle of the pond (Fig. 1, station 3). $5 \mathrm{~mL}$ of lugol were immediately added to preserve algae before qualitative and quantitative analyses.

\subsection{Thermodynamic equilibrium calculations}

The visual Minteq software version 2.61 (Gustafsson 2012) was used to calculate the saturation index of calcite in the overlying water (Eqn 1):

$$
\text { SI }=\log \frac{\left\{\mathrm{Ca}^{2+}\right\}\left\{\mathrm{CO}_{3}^{2-}\right\}}{K_{\mathrm{S}}},
$$

where $\left\{\mathrm{Ca}^{2+}\right\}$ and $\left\{\mathrm{CO}_{3}^{2-}\right\}$ are the activities of $\mathrm{Ca}^{2+}$ and $\mathrm{CO}_{3}^{2-}$ species at the thermodynamic equilibrium and $K_{\mathrm{s}}$ the solubility product of $\mathrm{CaCO}_{3}$. Calculations were undertaken from the following input data: $\mathrm{pH}$, alkalinity, temperature values and the concentrations of $\mathrm{Ca}^{2+}, \mathrm{NO}_{3}^{-}, \mathrm{Mg}^{2+}, \mathrm{Na}^{+}, \mathrm{Cl}^{-}, \mathrm{SO}_{4}^{2-}$ and $\mathrm{PO}_{4}^{3-}$ components.

\subsection{Barley straw treatment procedure}

The amount of barley straw (Hordeum vulgare) has been calculated from the surface of the pond according to CEH (2004), 3 tons of straw being necessary to achieve the recommended value of $50 \mathrm{~g}$ of straw per $\mathrm{m}^{2}$. Barley straw was introduced in 150 loosely packed rolls that were prepared on site using a tree-wrapping machine and $3 \mathrm{~km}$ of tubular netting. Rolls were then attached on five anchorage floating structures. Additionally, 50 buoys were added to insure the flotation of the rolls and to permit the degradation of barley straw under aerobic conditions during the monitoring experiment (Waybright et al. 2009). Barley straw was introduced in the pond in the beginning of May 2010.

\section{Results and discussion}

\subsection{Physico-chemical characterisation of the overlying water}

The physico-chemical parameters recorded in the overlying water show a good homogeneity between the five stations during the monitoring experiment (Table 1). Temperature values increase from $5.8{ }^{\circ} \mathrm{C}$ in late February to a maximum of $24.8{ }^{\circ} \mathrm{C}$ in July, then decreasing back to $9.7^{\circ} \mathrm{C}$ in November. Conductivity values range from 400 to $480 \mu \mathrm{S} \mathrm{cm} \mathrm{cm}^{-1}$ during the experiment with maxima occurring in July, because of higher temperatures and lower rainfalls compared to winter time. The whole water body of the Pont-Rouge Pond is generally well oxygenated with a supersaturation during daytime throughout the year, with the exceptions of July and August when saturation dropped down to $80 \%$ (Table 1). However, these measurements were done twice a month and one cannot exclude short anoxic events during a few days, particularly close to the water-sediment interface.

$\mathrm{pH}$ values ranged between 7.7 and 8.8 , in accordance with the carbonate-rich geological background. $\mathrm{pH}$ evolution during the monitoring period was probably mostly related to the primary production that consumed dissolved $\mathrm{CO}_{2}$ in the daytime and released it during the night. However, hydrogen carbonate concentrations were generally constant with alkalinity values in the range of $1.6-2.8 \mathrm{mmol} \mathrm{L}^{-1}$ (Table 1). The lowest alkalinity values on 20 May, 4 June and 18 August corresponded to higher levels of ammonium, nitrate and nitrite, revealing organic matter degradation processes.

Finally, the values of turbidity (4.9-29.6 FNU) and water transparency $(0.4-1.3 \mathrm{~m})$ (Table 1$)$ indicated that light did not penetrate deep into the water column. Therefore, this shallow euphotic zone would tend to enhance the development of cyanobacterial species adapted to low luminosity, for instance, Planktothrix sp. (Schwaderer et al. 2011; von Sperling et al. 2008).

\subsection{Geochemical properties of sediments}

Porosity and water contents in surface sediments were relatively high with values equal to $80 \%$ and $90 \%$, respectively. In deeper depths, sediments were settled with significant differences according to the sampling sites: at $10-\mathrm{cm}$ depth, the water percentage was $72 \%$ in station 2 and only $27 \%$ at station 3 . Granulometric distributions were also estimated and pointed out a heterogeneity of sediments, dominated by clay particles (size $<4 \mu \mathrm{m}$ ), followed by silty particles $(4<$ size $<63 \mu \mathrm{m}$ ). The sandy fraction was negligible in all sampling sites with less than $1 \%$ of the total fraction.

Redox potential values (given against the reference $\mathrm{Ag} / \mathrm{AgCl},[\mathrm{KCl}]=3 \mathrm{M}$ electrode) were positive above the water-sediment interface and dropped drastically in the first $4 \mathrm{~cm}$ of the sedimentary column with an amplitude of 400-700 mV (Fig. 3). These profiles indicate clearly that early diagenetic processes mediated by bacterial activity occurred in sediments. For the aquatic ecosystem of the Pont-Rouge Pond, the sediment pool acts as a 


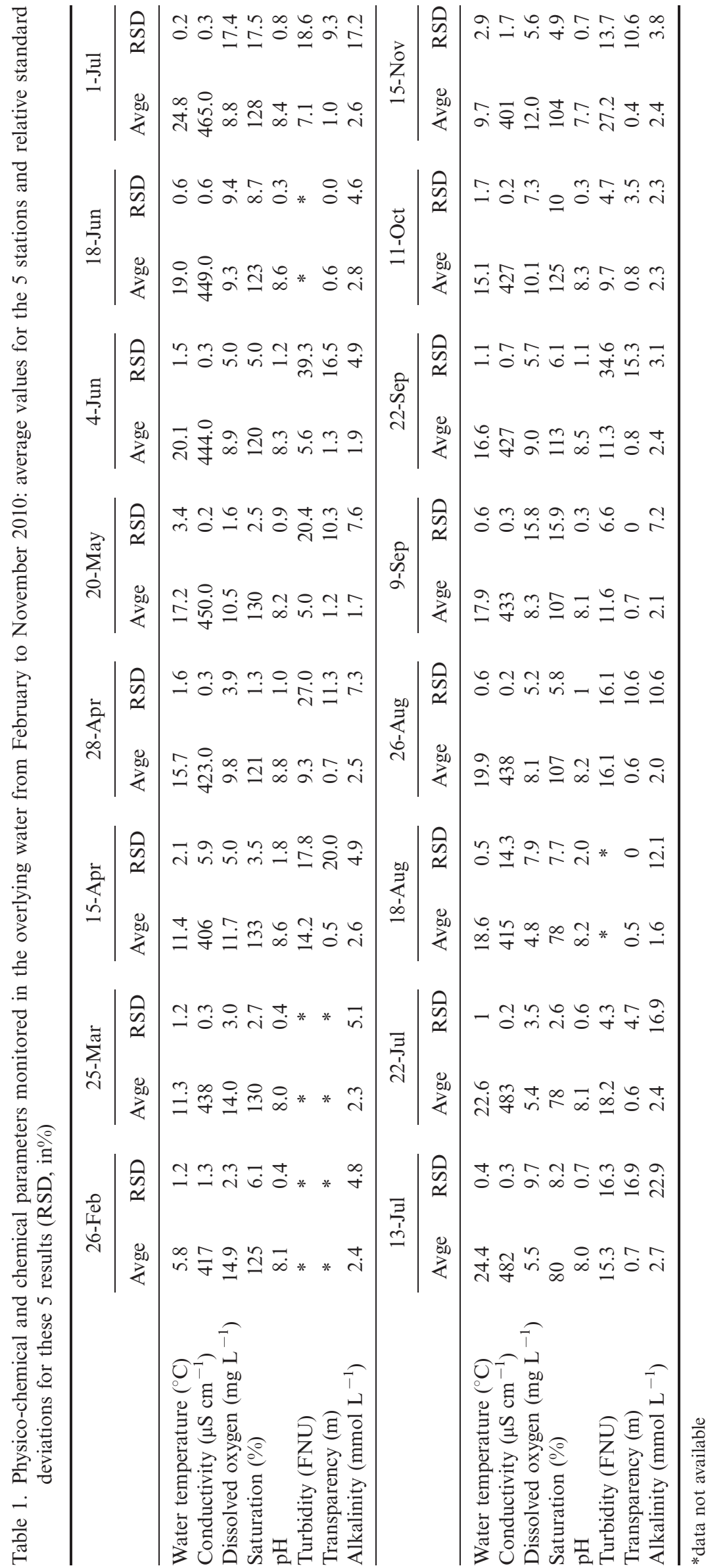



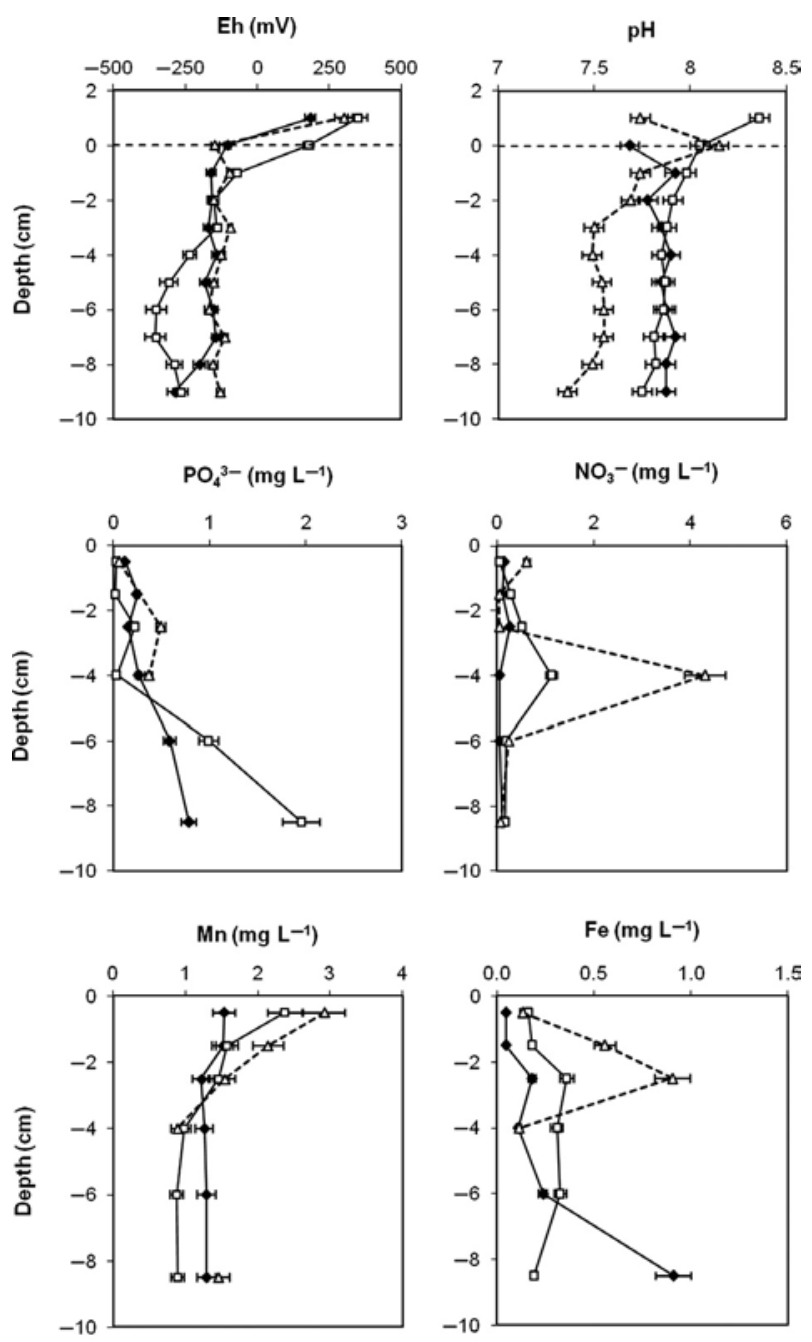

$\rightarrow$ Station $1 \quad \longrightarrow$ Station $2 \quad-\Delta-$ Station 3

Fig. 3. Depth profiles of $\mathrm{Eh}$ (in $\mathrm{mV} v$. $\mathrm{Ag} / \mathrm{AgCl}$ ), $\mathrm{pH}$ and concentrations (in $\mathrm{mg} \mathrm{L}^{-1}$ ) of nitrate, phosphate, iron and manganese in the dissolved phase of sedimentary pore waters (sampling stations 1,2 and 3). Negative values in the $y$-axis correspond to depths in the sediment core

bioreactor consuming quantitatively dissolved oxygen present close to the water-sediment interface. Just below, the consumption of oxygen by bacterial biomass, i.e. the biologically mediated reduction of nitrate, manganese and iron (hydr)oxides, occurred in sediment. The production of $\mathrm{Mn}^{2+}$ and $\mathrm{Fe}^{2+}$ in pore waters was clearly evidenced with concentrations much higher than in overlying waters: $880-2900 \mathrm{mg} \mathrm{L}^{-1}$ for $\mathrm{Mn}$ compared to $2-60 \mu \mathrm{g} \mathrm{L}^{-1}$ in overlying waters, and $45-4900 \mathrm{mg} \mathrm{L}^{-1}$ for $\mathrm{Fe}$ compared to $10-98 \mu \mathrm{g} \mathrm{L}^{-1}$ in overlying waters (Fig. 3).

As predicted by thermodynamic data, the Mn (hydr)oxides reduction occurs at higher redox potential than that of $\mathrm{Fe}$ (hydr)oxides, explaining the high concentrations of $\mathrm{Mn}^{2}+$ observed at $0.5 \mathrm{~cm}$ depth, whereas $\mathrm{Fe}^{2+}$ concentrations started to increase significantly from $1-$ to $2-\mathrm{cm}$ depth. These profiles also indicated that the oxic and hypoxic conditions, related to biodegradable organic matter mineralisation processes, were probably restricted to the very upper layers of sediments and that phosphate release may occur quickly in case of anoxic processes at the watersediment interface (see Section 2.3).

\subsection{Nitrogen and phosphorus behaviour in relation with algal development}

In the Pont-Rouge Pond, Chl- $a$ concentrations ranged from 8 to $83 \mu \mathrm{g} \mathrm{L}^{-1}$ during the monitoring experiment (Table 1). In February and November, values remained relatively high of around $35 \mu \mathrm{g} \mathrm{L}^{-1}$, explaining at least partly why phosphate was consumed all along the year without any regeneration during winter time (see thereafter). Significant decrease in Chl- $a$ values took place after maxima observed in mid-April and in midJune, indicating a quick degradation of primary production. However, phaeopigments (Phaeo) concentrations did not increase significantly during these periods and the ratio Chl- $a$ / Phaeo remained higher than 1. Generally, it seems that primary production is active all along the year with a continuous recycling of dead organisms. In these conditions, sudden input of detrital material that would consume quantitatively and quickly dissolved oxygen was rather limited. As a consequence, no anoxia bound to the mineralisation of freshly died algal cells has been noticed.

The evolution of phytoplankton composition was determined from March to October 2010 (Fig. 4). In March 2010, phytoplankton was dominated by flagellated Chrysophyceae (class of Chromophyceae), and particularly by the species Erkena sp. In spring, centric diatoms (mostly represented by Stephanodiscus sp.) colonised the pond. At the same time, green algae started developing, with a predominance of Ankyra lanceolata in May. From June, cyanobacteria were detected, sometimes at high density: Aphanizomenon $s p$. dominated three times the algal population (04 June 2010, 17 July 2010 and 22 July 2010) and A. flos-aquae development resulted in a scum on 4 June at the surface of the pond. At the end of summer, Aphanocapsa sp, Coelomoron sp and Anabaena sp were punctually the main algal species. Finally, a minimal diversity (12 taxons) was measured in May-June, whereas a maximal diversity of 56 taxons was observed at the end of August.

Although a regular manual sampling was carried out monthly, or even every two weeks, allows the observation of some changes in algal species and their concentrations, the dynamic of the phytoplankton behaviour can only be evidenced by an increasing number of measurements. The high-frequency monitoring using the Algae Online Analyser (AOA, BBE moldaenke) confirmed the end of the diatom blooms in late April (Fig. 5) followed by a clear water period with low Chl- $a$ values. 


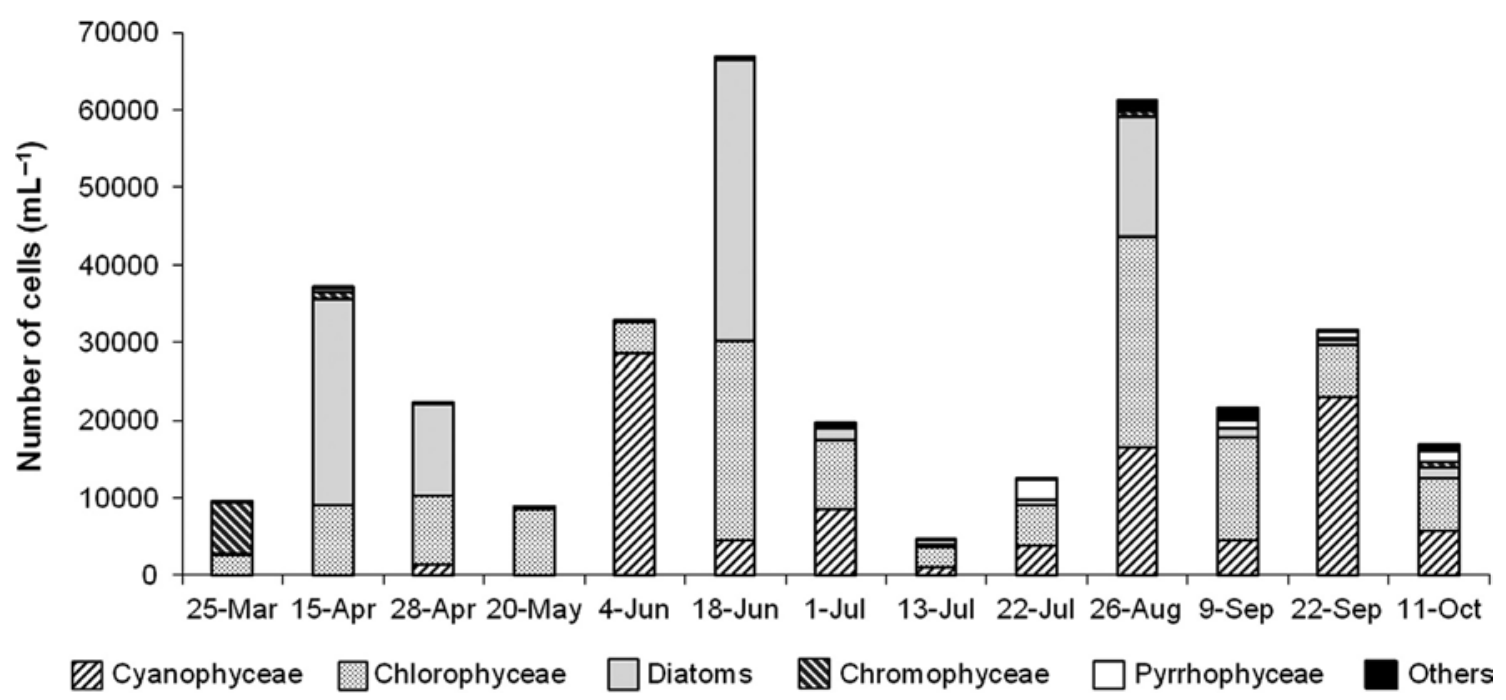

Fig. 4. Evolution of phytoplankton main groups in the overlying water of the Pont-Rouge Pond: Cyanophyceae, Chlorophyceae, Diatoms, Chromophyceae (without Diatoms), Pyrrhophyceae and others (included Euglenophyceae and undetermined species)

From the beginning of May, an increase of green algae was recorded (with higher Chl- $a$ concentrations). On 24 May, cyanobacteria started to develop and from 4 June, their concentrations $\left(10 \mu \mathrm{g} \mathrm{L}^{-1}\right)$ were higher than those of green algae (approximately $3 \mu \mathrm{g} \mathrm{L}^{-1}$ ) leading to a visible bloom of Aphanizomenon flos-aquae. This sharp view of algal succession clearly evidenced that the growth rate of each algal species took place at the timescale of the day. For instance, diatoms and cyanobacteria species were only significantly detected over approximately 1-2 weeks in May and June 2010 and their amounts were multiplied by $10-20$ within $2-3$ days. These quick evolutions can be linked to the grazing pressure by zooplankton and other invertebrates, the change of physico-chemical conditions and/ or weather, although no direct correlation has been established between these primary production events and luminosity, rainfall and/or temperature during the high-frequency monitoring.

\subsubsection{Nitrogen}

Nitrate, ammonium and nitrite were recorded periodically in the 5 sampling stations at $50 \mathrm{~cm}$ below water surface (Table 2). Concentrations were homogeneous in the whole pond, with the exceptions of periods characterised by low concentrations or bloom events. Nitrate concentrations decreased progressively between February and April to values below $0.1 \mathrm{mg} \mathrm{L}^{-1}$. Between May and August, erratic variations were observed with maximal concentrations similar to those recorded in winter.

As a consequence, the development of algal species during spring was followed by punctual nitrification processes. For instance, a green algae rapid growth occurred at the end of May-beginning of June. The mineralisation of the phytoplankton biomass resulted in a release of ammonium rapidly oxidised in nitrate due to the presence of dissolved oxygen. This process resulted also in the production of nitrite with concentrations raising $0.2 \mathrm{mg} \mathrm{L}^{-1}$. These high contents corresponded to an enrichment of approximately 10 times the background nitrite concentrations.

However, the increases of nitrite and ammonium concentrations were limited because of an efficient oxygenation of the pond during all seasons. Between June and September, nitrate concentrations remained low indicating that this nutritive salt could limit algal development (see thereafter). In pore-water sediments, nitrate was quantitatively consumed and concentrations dropped generally down to the LOD $(\mathrm{LOD}=$ $0.1 \mathrm{mg} \mathrm{L}^{-1}$ ) within the first centimetre. However, some local maxima were observed probably due to bioturbation and local nitrification processes. Overall, the results clearly showed that the sediments did not act as a source of nitrate for the pond water column, but rather as a denitrification reactor producing gaseous di-nitrogen $\left(\mathrm{N}_{2}\right)$ by the bacterial activity as mentioned previously (Mortimer et al. 2004).

\subsubsection{Phosphorus}

In shallow water bodies, where the water depth does not exceed a few metres (including rivers, ponds and lakes), phosphorus cycle is dependent on a multitude of biogeochemical parameters both in the water column and in surface sediments.

In these environments, the recycling of DRP in the water column during winter is barely observed and more complex pathways are rather proposed to explain the behaviour of phosphorus and its link with primary production (House 2003). In the Pont-Rouge Pond, DRP concentrations were lower in winter than in summer (Table 2), suggesting an input of phosphate 

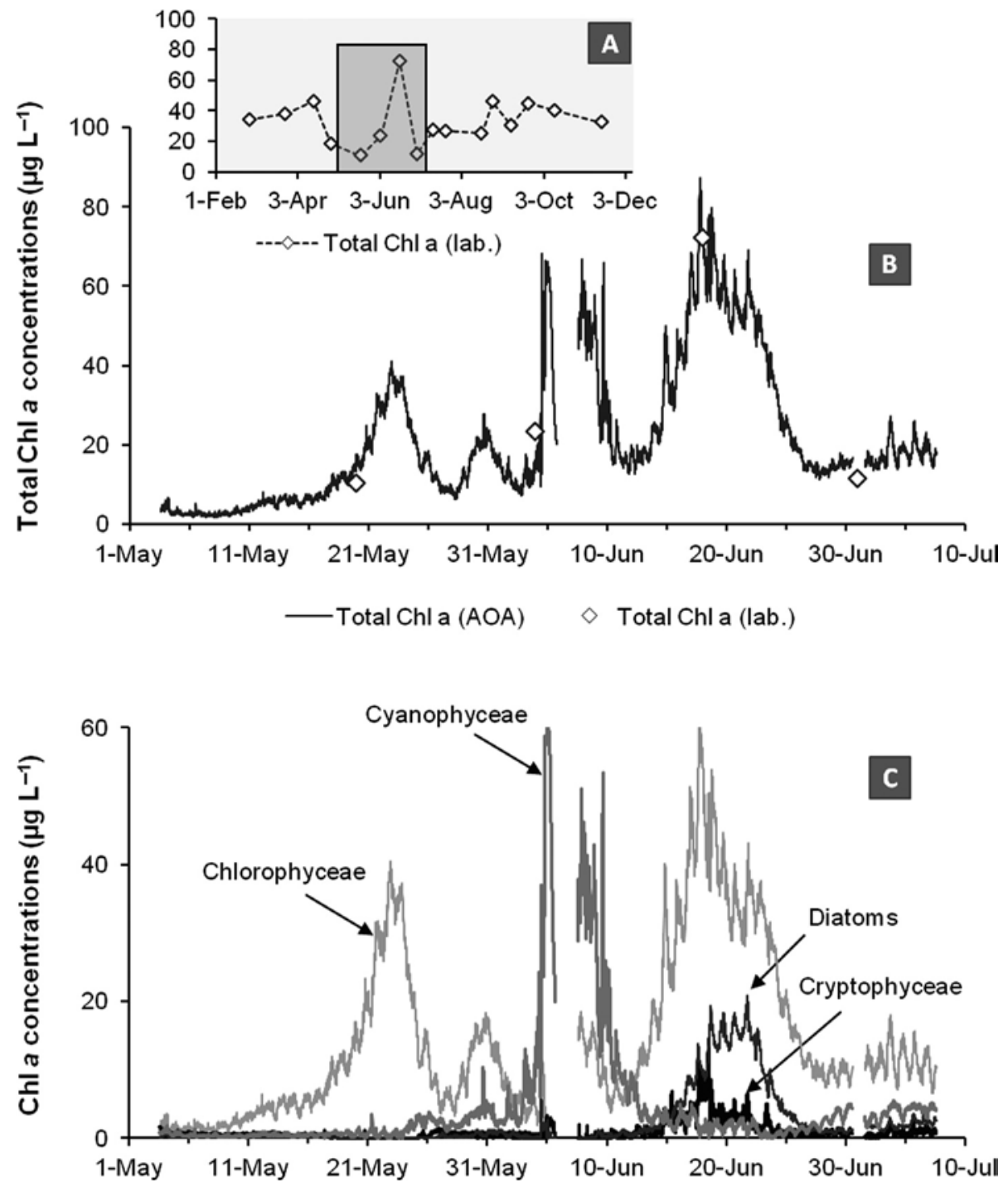

Fig. 5. Chlorophyll $a$ concentrations (in $\mu \mathrm{g} \mathrm{L}^{-1}$ ) in the overlying water of the pond. A, total concentrations determined by the laboratory procedure (period February-November 2010, average for the 5 stations). B, total concentrations monitored by the Algae Online Analyser (AOA) (period May-July 2010). C, concentrations of phytoplankton species monitored by the AOA (period May-July 2010)

from sediment to the overlying water. As phosphorus cycle depends on numerous physical, chemical and biological parameters (House 2003), a complete understanding of this cycle was not achieved. However, several essential points, closely related to the main purposes of this article, need to be underlined in this relatively closed system: (1) during winter, DRP concentrations in overlying waters were quite high indicating that the pond can be considered as eutrophic to hypereutrophic according to the Carlsons's Trophic State Index; (2) in early spring, an increasing primary production corresponded to a decrease of DRP concentrations due to assimilation processes; and (3) from the beginning of May, DRP concentrations increased again to values up to $300-400 \mu \mathrm{g} \mathrm{L}^{-1}$.

This relevant input of DRP in the pond is probably not bound to external inputs, since no important tributaries or agricultural activities charged the pond significantly. Most probably, surface sediments should play a key role in the cycle of phosphorus.

In sediment pore waters, DRP concentrations increased with depth (Fig. 3) because of (1) the mineralisation of organic matter by bacterial activity that produced inorganic phosphorus; (2) the reduction of iron (hydr)oxides on which exchangeable phosphate was initially bound to and; (3) a drop of $\mathrm{pH}$ values of approximately 0.5 unit compared to those measured in the overlying water that both contributed to desorb a fraction of phosphate and to partly dissolve carbonates in which phosphate was co-precipitated (House 2003). However, in the first centimetre of sediments, DRP concentrations remained low as a consequence of the presence of an iron oxide layer that additionally hampered, at least partially, the diffusion of phosphate 
Table 2. Concentrations of nitrate, nitrite, ammonium, phosphate, iron and manganese (in $\mu \mathrm{g} \mathrm{L}^{-1}$ ) in the overlying water from February to November 2010: average values for the 5 stations and relative standard deviations for these 5 results $(\mathrm{RSD}, \mathrm{in} \%)$

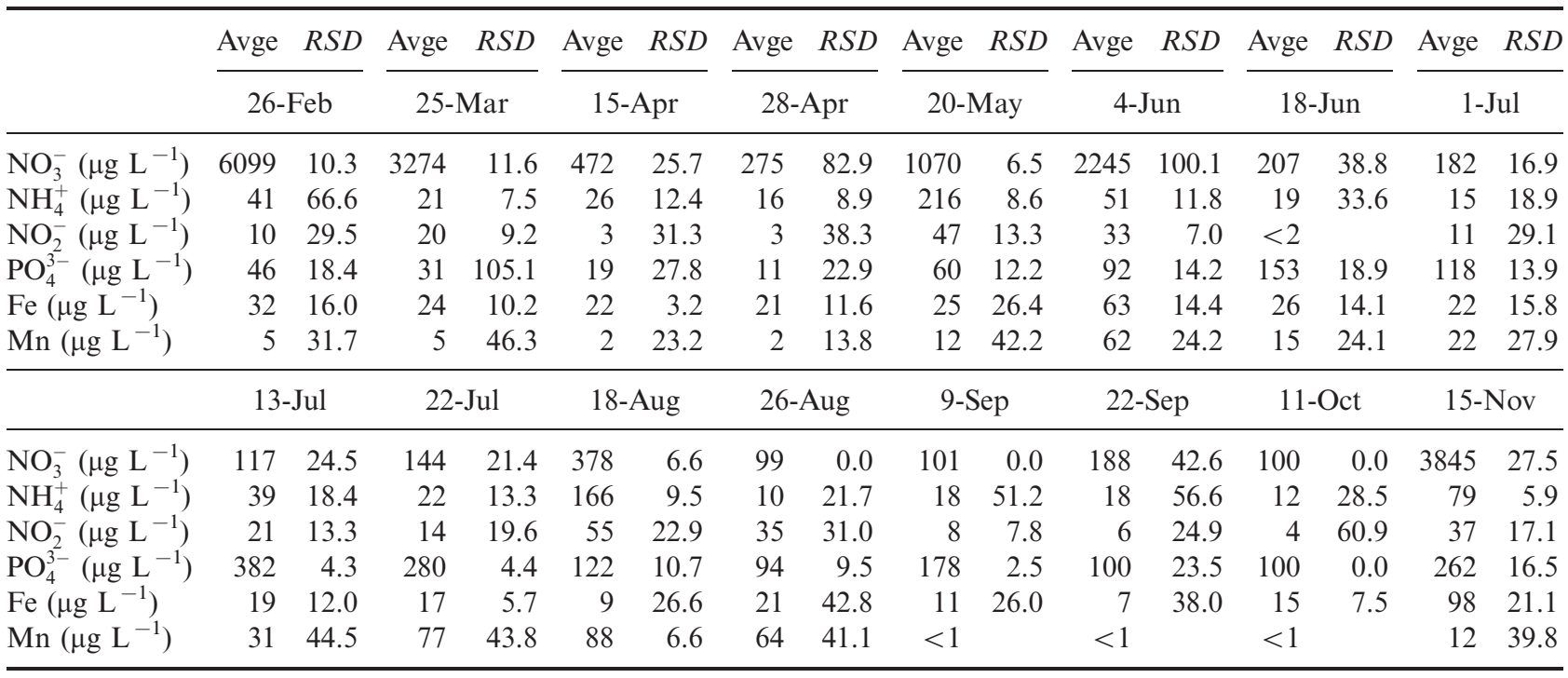

back to overlying waters. Analyses of total phosphorus (TP) concentrations in sedimentary particles revealed that concentrations were maximal close to the water interface at around $1.0-1.2 \mathrm{~g} \mathrm{~kg}^{-1}$, and decreased with depth down to $0.6-0.8 \mathrm{mg} \mathrm{kg}^{-1}$, depending on the sampling station (data not shown). These profiles indicated that the (hydr)oxides layer (and probably to a lesser extent carbonates' minerals) present in surface sediments accumulated efficiently a large amount of DRP, resulting in strong opposite gradient of dissolved DRP and TP concentrations in the sediment column (Anschutz et al. 2007; Kleeberg et al. 2010). The high amount of exchangeable phosphate at the watersediment interface can be considered in this system as a temporal sink for phosphorus, but also as a potential source of DRP for the pond in case of anoxic processes. Anoxic sediment resuspension (for instance, by bioturbation) or degradation of detrital organic matter after a phytoplankton bloom could consume quantitatively the remaining oxygen present in sediment, and particularly that contained in iron (hydr)oxides, leading to a quick release of DRP in overlying water (PalmerFelgate et al. 2011, and references therein).

Previous studies pointed out the scavenging of DRP excessive input by calcite co-precipitation (House 2003). According to Merz-Prei $\beta$ and Riding (1999), this generally occurs when calcite saturation indexes $\left(\mathrm{SI}_{\text {calcite }}\right)$ are higher than 0.8. In this study, $\mathrm{SI}_{\text {calcite }}$ punctually reached values higher than $1 ; \mathrm{CO}_{2}$ consumption by the photosynthetic activity resulted in a $\mathrm{pH}$ enhancement favourable for $\mathrm{CaCO}_{3}$ precipitation. However, no significant correlation was found between $\mathrm{SI}_{\text {calcite }}$ and DRP concentrations and a direct precipitation of DRP with $\mathrm{Ca}$ was also possible since hydroxyapatite SI was generally positive. Nevertheless, as the concentration of DRP remained much lower than $4.8 \mathrm{mg} \mathrm{L}^{-1}$, the crystal nucleation of apatite phases did not occur easily (Plant, House 2002). These findings suggest that, in the overlying waters, the chemical control of DRP mobility by $\mathrm{Ca}$ minerals should probably not be the main process. Note further that, despite the high primary production occurring in the pond, dissolved phosphate concentrations were generally higher than $50-100 \mu \mathrm{g} \mathrm{L}^{-1}$ and the $\left[\mathrm{NO}_{3}^{-}\right] /$ $\left[\mathrm{PO}_{4}^{3-}\right]$ ratio values were higher than 16 until beginning of June, and then dropped down to 5. From this time, nitrate became the limiting factor and its low concentrations $\left(<100 \mu \mathrm{g} \mathrm{L}^{-1}\right)$ resulted in the relative limitation of algal development that gave heterocystous cyanobacteria the opportunity to grow because of their ability to assimilate gaseous di-nitrogen. However, DRP concentrations in the pond still increased during this period, suggesting a significant release of dissolved phosphate from sediments due to anoxic processes at the water-sediment interface (Lake et al. 2007; Xie et al. 2003). That occurs particularly after an algal bloom when high amounts of detrital organic matter settled onto surface sediments and are degraded by bacterial activity.

\subsection{Impact of the barley straw treatment}

In the Artois-Picardie watershed, cyanobacteria blooms were limited due to relatively bad weather conditions occurring in this period. For instance, the monthly average air temperatures were $19.3^{\circ} \mathrm{C}$ in June, $20.2^{\circ} \mathrm{C}$ in July, $17.0^{\circ} \mathrm{C}$ in August and $14.5^{\circ} \mathrm{C}$ in September. As for precipitation, rainy periods occurred mainly in August with $132 \mathrm{~mm}$ of water equivalent against 29,67 and $75 \mathrm{~mm}$ in June, July and September, respectively. Additionally, it has been shown that, during the monitoring 
period, blooms were limited in time and a two-week sampling frequency was not sufficient to account for all of them in the Pont-Rouge Pond.

According to CEH (2004), the effects of barley straw strongly depend on water temperature. For an average temperature higher than $20^{\circ} \mathrm{C}$, the effect of straw degradation starts within $4-5$ weeks after its watering and the renewing of the treatment is necessary after 4-6 months. For temperatures lower than $20{ }^{\circ} \mathrm{C}$, the degradation of straw is slower and the effect on phytoplankton, probably linked to the production of polyphenols, starts 8-10 weeks after its watering. The renewing of straw is, in this latter case, recommended after 8-10 months. In our study, the temperature of the overlying water was on average equal to $18.5{ }^{\circ} \mathrm{C}$ in May-June 2010 that would promote an algistatic action of the straw from the beginning of July. This action would also end approximately on December 2010 because of an average temperature between July and October of $19{ }^{\circ} \mathrm{C}$.

In the beginning of June, the bloom of $A$. flos aquae cannot be stopped, or at least hampered, by the degradation of straw. The development of this species and that of Anabaena sp as well is however known to be inhibited by barley straw decomposition (Brownlee et al. 2003; Rajabi et al. 2010) and in July, they completely disappeared. However, in October, Anabaena sp reappeared and dominated the algal population. Overall, the diversity of the cyanobacteria species was poor from April to June (1-2 species) and strongly increased in the beginning of July when six species were registered, although the decomposition of barley straw should have hampered the development of cyanobacteria. However, this richness disappeared quickly and only one species, Aphanizomenon $s p$ dominated in summer. In the literature (Brownlee et al. 2003; Rajabi et al. 2010), this species should have been inhibited by barley straw decomposition that was not the case in this pond.

The values of Chl- $a$ concentrations and number of cells per $\mathrm{mL}$ were also monitored every two weeks in the pond (Figs 4 and 5). A maximum of both parameters was observed in the middle of June (Chl- $a=72 \mu \mathrm{g} \mathrm{L}^{-1}$ and 66,800 cell $\mathrm{mL}^{-1}$ ) and the values dropped down quickly to approximately $25 \mu \mathrm{g} \mathrm{L}^{-1}$ of Chl- $a$ and 12,600 cell mL ${ }^{-1}$ from the middle of July to the end of August. Although the effect of barley straw decomposition cannot be totally excluded, the bad weather conditions in July and August may be the main factors limiting algal development. Indeed, the increase of irradiance at the end of August resulted in a quick increase of Chl- $a$ concentrations by a factor 2 .

The algal species present in 2010 have already been observed for several years (Anabaena $s p$ in 1990 and 2003, Aphanizomenon $s p$ in 2003, 2004 and 2005), but some others were totally absent this year (for instance, Plankthotrix agardhii). The interpretation of the data is however not so trivial: barley straw has indeed an algistatic effect on some species like Microcystis, Anabaena or Aphanizomenon sp. (Brownlee et al. 2003; Rajabi et al. 2010), while it may stimulate the development of some others, for instance, Anabaena cylindrica or Oscillatoria (Rajabi et al. 2010). Additionally, several studies counteracted these findings, especially concerning Microcystis sp (Ferrier et al. 2005; Ó hUallacháin, Fenton 2010). In parallel, the monitoring of phytoplankton carried out in the Artois-Picardie basin (data not shown) has clearly shown that in 2010, A. flos-aqua was never observed in other ponds, while Aphanizomenon $s p$ was strongly present in summer, like in the Pont-Rouge Pond.

In a more technical and operational point of view, the introduction of barley straw treatment in water bodies of this size appears to be difficult. Indeed, the packaging and deployment of barley straw on the pond required a total workforce estimated to 250 hours per year. The choice of the location of the straw rolls was also not optimised because the pond is used for leisure activities and it was not possible to spread the rolls everywhere. The preservation of barley straw rolls at the water surface was operated by the use of 50 buoys and 5 anchorage floating structures that finally were not sufficient enough to ensure the complete flotation of straw. Furthermore, the degradation of barley straw was not as rapid as predicted in previous studies (CEH 2004). It was shown that the degradation occurred within three to four months, while in our case, a significant quantity of straw remained after seven months of deployment. This relatively low degradation rate may be due to the swelling of the straw and to the high suspended matter levels in the pond resulting in the rapid covering of straw by particles. Altogether, this could have limited the penetration of oxygen (average concentration measured inside the bales was approximately $6 \mathrm{mg} \mathrm{L}^{-1}$ ) and UVlight and thus the efficiency of the treatment (Boylan, Morris 2003). Moreover, the treatment appeared to be more efficient when applied with finely chopped straw (2-mm size) (Iredale et al. 2012). In that case, a dosage of $5 \mathrm{~g} \mathrm{~L}^{-1}$ (dry weight) was sufficient to observe an inhibitory activity. However, it must be highlighted that this value largely exceeds our field dosage (approximately $12.5 \mathrm{~g} \mathrm{~m}^{3}$ ). Another weak point was the monitoring of barley straw degradation due to the unknown operating conditions which lead to the release of algistatic compounds. For instance, polyphenolic compounds are not easy to measure at trace levels and the spectrophotometric method we tested (Grubešic et al. 2005) on several samples was not sensitive enough.

\section{Conclusion}

1. Small and shallow floodplain ponds are very reactive environments characterised by intense exchanges between sediments, interstitial water 
and open water. This kind of pond is very common in Northern France and large and specific attention has been paid to this problem because of phytoplankton developments and particularly harmful cyanobacteria blooms, which have consequences both on aquatic environments and water usage.

2. Numerous algal treatments have been tested for more than 20 years in the Pont-Rouge Pond (Le Quesnoy city) but remained unsuccessful. In 2010-2011, the efficiency of the treatment based on barley straw presented in this paper, was not clearly evidenced and the question arose on the interest of barley straw to help fighting against algae and cyanobacteria for large ponds, especially because they require enormous investments in terms of means and time.

3. The persistence of an algal activity, including during the winter period, allowed a high oxygen content in the water column and thus the presence of $\mathrm{Fe}$ and $\mathrm{Mn}$ oxides at the watersediment interface that prevent sediment phosphorus release.

4. The development of cyanobacteria blooms from early June did not result in anoxia due to the rapid and effective recycling of organic matter. However, the mineralisation capacities of the pond could be overpassed if algae blooms become larger and more frequent and, consequently, a phosphorus release from sediment could occur as its concentration is about $1 \mathrm{~g} \mathrm{~kg}^{-1}$ dry weight.

5. For small and shallow flood plain ponds, it is therefore essential to take into account both the phosphorus internal load and sedimentwater phosphorus exchange dynamics when defining water phosphorus thresholds as required by the EU water Framework Directive.

\section{Acknowledgements}

This study was supported by the cooperation agreement between the Artois-Picardie French Water Agency and the University of Lille 1 . The authors thank the town council of Le Quesnoy, Espace Naturel Lille Metropole (ENLM) and the local fishing association for their logistic help during the preparation and deployment of barley straw. The technical help of Michel Arold (French Water Agency), Olivier Boulinguez and Damien Comblez (ENLM), and Christine Grare (University of Lille 1) were also appreciated. We dedicate this work to our colleague, Guy Thoumelin, who contributed to the supervision of this project until his sudden death in April 2010.

\section{References}

Anschutz, P.; Chaillou, G.; Lecroart, P. 2007. Phosphorus diagenesis in sediment of the Thau Lagoon, Estuarine,
Coastal and Shelf Science 72(3): 447-456. http://dx.doi.org/10.1016/j.ecss.2006.11.012

Bai, X. L.; Ding, S. M.; Fan, C. X.; Liu, T.; Shi, D.; Zhang, L. 2009. Organic phosphorus species in surface sediments of a large, shallow, eutrophic lake, Lake Taihu, China, Environmental Pollution 157: 2507-2513. http://dx.doi.org/10.1016/j.envpol.2009.03.018

Boylan, J. D.; Morris, J. E. 2003. Limited effects of barley straw on algae and zooplankton in a midwestern pond, Lake and Reservoir Management 19(3): 265-271. http://dx.doi.org/10.1080/07438140309354091

Brownlee, E. F.; Sellner, S. G.; Sellner, K. G. 2003. Effects of barley straw (Hordeum vulgare) on freshwater and brackish phytoplankton and cyanobacteria, Journal of Applied Phycology 15(6): 525-531. http://dx.doi.org/10.1023/b:japh.0000004353.15684.25

Cao, Z.; Zhang, X.; Ai, N. 2011. Effect of sediment on concentration of dissolved phosphorus in the Three Gorges Reservoir, International Journal of Sediment Research 26(1): 87-95. http://dx.doi.org/10.1016/S1001-6279(11)60078-4

CEH. 2004. Information sheet 1: control of algae with barley straw. Wallingford, UK: Centre for Ecology and Hydrology.

Everall, N. C.; Lees, D. R. 1997. The identification and significance of chemicals released from decomposing barley straw during reservoir algal control, Water Research 31(3): 614-620. http://dx.doi.org/10.1016/S0043-1354(96)00291-6

Ferrier, M. D.; Butler Sr., B. R.; Terlizzi, D. E.; Lacouture, R. V. 2005. The effects of barley straw (Hordeum vulgare) on the growth of freshwater algae, Bioresource Technology 96(16): 1788-1795. http://dx.doi.org/10.1016/j.biortech.2005.01.021

Grover, J. P.; Baker, J. W.; Ureña-Boeck, F.; Brooks, B. W.; Errera, R. M.; Roelke, D. L.; Kiesling, R. L. 2007. Laboratory tests of ammonium and barley straw extract as agents to suppress abundance of the harmful alga Prymnesium parvum and its toxicity to fish, Water Research 41(12): 2503-2512. http://dx.doi.org/10.1016/j.watres.2007.03.025

Grubešić, R. J.; Vuković, J.; Kremer, D.; Vladimir-Knežević, S. V. 2005. Spectrophotometric method for polyphenols analysis: prevalidation and application on Plantago L. species, Journal of Pharmaceutical and Biomedical Analysis 39(3-4): 837-842. http://dx.doi.org/10.1016/j.jpba.2005.05.004

Gustafsson, J. P. 2012. Visual MINTEQ, version 2.61 [online]. Available from Internet: http://www2.lwr.kth. se/English/OurSoftware/vminteq/index.html

Hagström, J. A.; Sengco, M. R.; Villareal, T. A. 2010. Potential methods for managing Prymnesium parvum blooms and toxicity, with emphasis on clay and barley straw: a review, Journal of the American Water Resources Association 46(1): 187-198. http://dx.doi.org/10.1111/j.1752-1688.2009.00402.x

House, W. A. 2003. Geochemical cycling of phosphorus in rivers, Applied Geochemistry 18(5): 739-748. http://dx.doi.org/10.1016/S0883-2927(02)00158-0 
Iredale, R. S.; McDonald, A. T.; Adams, D. G. 2012. A series of experiments aimed at clarifying the mode of action of barley straw in cyanobacterial growth control, Water Research 46(18): 6095-6103.

Khan, F.; Ansari, A. 2005. Eutrophication: an ecological vision, The Botanical Review 71(4): 449-482. http://dx.doi.org/10.1663/0006-8101(2005)071\%5B0449: EAEV \% 5D2.0.CO;2

Kisand, A. 2005. Distribution of sediment phosphorus fractions in hypertrophic strongly stratified Lake Verevi, Hydrobiologia 547: 33-39. http://dx.doi.org/10.1007/s10750-005-4141-2

Kleeberg, A.; Herzog, C.; Jordan, S.; Hupfer, M. 2010. What drives the evolution of the sedimentary phosphorus cycle?, Limnologica - Ecology and Management of Inland Waters 40(2): 102-113. http://dx.doi.org/10.1016/j.limno.2009.11.001

Lake, B. A.; Coolidge, K. M.; Norton, S. A.; Amirbahman, A. 2007. Factors contributing to the internal loading of phosphorus from anoxic sediments in six Maine, USA, lakes, Science of the Total Environment 373(2-3): 534-541. http://dx.doi.org/10.1016/j.scitotenv.2006.12.021

Le Jeune, A.-H.; Charpin, M.; Deluchat, V.; Briand, J.-F.; Lenain, J.-F.; Baudu, M.; Amblard, C. 2006. Effect of copper sulphate treatment on natural phytoplanktonic communities, Aquatic Toxicology 80(3): 267-280. http://dx.doi.org/10.1016/j.aquatox.2006.09.004

Merz-Preiß, M.; Riding, R. 1999. Cyanobacterial tufa calcification in two freshwater streams: ambient environment, chemical thresholds and biological processes, Sedimentary Geology 126(1-4): 103-124. http://dx.doi.org/10.1016/S0037-0738(99)00035-4

Mortimer, R. J. G.; Harris, S. D.; Krom, M. D.; Freitag, T. E.; Prosser, J. I.; Barnes, J.; Anschutz, P.; Hayes, P. J.; Davies, I. M. 2004. Anoxic nitrification in marine sediments, Marine Ecology Progress Series 276: 37-51. http://dx.doi.org/10.3354/meps276037

Newcombe, G.; Chorus, I.; Falconer, I.; Lin, T. F. 2012. Cyanobacteria: impacts of climate change on occurrence, toxicity and water quality management, Water Research 46(5): 1347-1348. http://dx.doi.org/10.1016/j.watres.2011.12.047

O'Neil, J. M.; Davis, T. W.; Burford, M. A.; Gobler, C. J. 2012. The rise of harmful cyanobacteria blooms: the potential roles of eutrophication and climate change, Harmful Algae 14: 313-334. http://dx.doi.org/10.1016/j.hal.2011.10.027

Ó hUallacháin, D.; Fenton, O. 2010. Barley (Hordeum vulgare)-induced growth inhibition of algae: a review, Journal of Applied Phycology 22(5): 651-658. http://dx.doi.org/10.1007/s10811-009-9492-Z

Paerl, H. W.; Fulton, R. S.; Granéli, E.; Turner, J. T. 2006. Ecology of Harmful Cyanobacteria, in Granéli, E.; Turner, J. T. (Eds.). Ecology of Harmful Algae. Berlin: Springer Verlag, 95-109. http://dx.doi.org/10.1007/978-3-540-32210-8

Palmer-Felgate, E. J.; Mortimer, R. J. G.; Krom, M. D.; Jarvie, H. P.; Williams, R. J.; Spraggs, R. E.; Stratford, C. J.
2011. Internal loading of phosphorus in a sedimentation pond of a treatment wetland: effect of phytoplankton crash, Science of the Total Environment 409: 2222-2232. http://dx.doi.org/10.1016/j.scitotenv.2011.02.034

Pẹczuła, W. 2013. Influence of barley straw (Hordeum vulgare L.) extract on phytoplankton dominated by Scenedesmus species in laboratory conditions: the importance of the extraction duration, Journal of Applied Phycology 25(2): 661-665. http://dx.doi.org/10.1007/s10811-012-9900-7

Plant, L. J.; House, W. A. 2002. Precipitation of calcite in the presence of inorganic phosphate, Colloids and Surfaces A: Physicochemical and Engineering Aspects 203(1-3): 143-153. http://dx.doi.org/10.1016/S0927-7757(01)01089-5

Purcell, D.; Parsons, S. A.; Jefferson, B.; Holden, S.; Campbell, A.; Wallen, A.; Chipps, M.; Holden, B.; Ellingham, A. 2013. Experiences of algal bloom control using green solutions barley straw and ultrasound, an industry perspective, Water and Environment Journal 27(2): $148-156$. http://dx.doi.org/10.1111/j.1747-6593.2012.00338.x

Rajabi, H.; Filizadeh, Y.; Soltani, M.; Fotokian, M. H. 2010. The use of barley straw for controlling of cyanobacteria under field application, Journal of Fisheries and Aquatic Science 5(5): 394-401. http://dx.doi.org/10.3923/jfas.2010.394.401

Schwaderer, A. S.; Yoshiyama, K.; Pinto, P. de T.; Swenson, N. G.; Klausmeier, C. A.; Litchman, E. 2011. Eco-evolutionary differences in light utilization traits and distributions of freshwater phytoplankton, Limnology and Oceanography 56(2): 589-598. http://dx.doi.org/10.4319/lo.2011.56.2.0589

von Sperling, E.; da Silva Ferreira, A. C.; Nunes Ludolf Gomes, L. 2008. Comparative eutrophication development in two Brazilian water supply reservoirs with respect to nutrient concentrations and bacteria growth, Desalination 226(1-3): 169-174. http://dx.doi.org/10.1016/j.desal.2007.02.105

Waybright, T. J.; Terlizzi, D. E.; Ferrier, M. D. 2009. Chemical characterisation of the aqueous algistatic fraction of barley straw (Hordeum vulgare) inhibiting Microcystis aeruginosa, Journal of Applied Phycology 21: 333-340. http://dx.doi.org/10.1007/s10811-008-9373

Willame, R.; Hoffmann, L. 2005. Les cyanobactéries (algues bleues) responsables d'efflorescences dans les eaux stagnantes. Aspects systématiques-écologiques-toxicologi ques [online]. Centre de Recherches Gabriel Lippmann, 125 p. Available from Internet: http://www.eau-artoispicardie.fr/IMG/BaseDoc/aegis/871/B\%2010727.pdf. (in French).

Xiang, S. L; Zhou, W. B. 2011. Phosphorus forms and distribution in the sediments of Poyang Lake, China, International Journal of Sediment Research 26(2): 230238. http://dx.doi.org/10.1016/S1001-6279(11)60089-9

Xie, L. Q.; Xie, P.; Tang, H. J. 2003. Enhancement of dissolved phosphorus release from sediment to lake water by Microcystis blooms: an enclosure experiment in a hyper-eutrophic, subtropical Chinese lake, Environmental Pollution 122(3): 391-399. http://dx.doi.org/10.1016/S0269-7491(02)00305-6 
Emilie PRYGIEL. PhD. University Lille 1. Publications: One paper in an international journal and five communications in international and national conferences. Research fields: water pollution, phytoplankton evolution, sediment resuspensions impacts on water quality, relationships between contamination and toxicity on invertebrates.

Adeline CHARRIAU. Associate Professor. University of Limoges. Publications: author/co-author of four scientific papers, nine communications in international conferences. Research fields: environmental chemistry, sediment and water contamination, passive sampling techniques.

Romain DESCAMPS. Technician. University Lille 1. Publications: two national technical reports for the French Water Agency and acknowledged six times within international papers. Technical interests: atomic absorption and emission spectroscopies, ICP-MS, ionic chromatography and wide water and sediment sampling expertise.

Jean PRYGIEL. Regional Water Agency (northern France), Associate Professor (University Lille 1). Publications: 20 articles in international journals and more than 30 communications in international conferences. Research fields: status and functioning of aquatic environments, networks monitoring, Framework Water Directive, eutrophication, biological indices, diatoms, impact of water and sediment contamination on biological quality.

Baghdad OUDDANE. Professor. University Lille 1. Publications: 78 papers in international journals and more than 120 communications in national and international conferences. Research fields: a wide range of environmental areas including: trace element speciation in natural waters and sediments, metal-ligand complexes, biogeochemical processes in river and marine environments and analytical chemistry development as a tool for monitoring of environmental processes.

Gabriel BILLON. Professor. University Lille 1. Publications: 40 articles in international journals and more than 60 communications in international conferences. Research fields: sulphur cycle and metal pollutants in the estuarine and riverine sediments during early diagenetic processes; biogeochemical transformations at the water-sediment interface and the effect of sediment resuspension on metal and Phosphorus mobility. 